\title{
Histo-Epidemiological Profile of Head and Neck Cancers in Benin
}

\author{
Spero H. Raoul Hounkpatin 1*, Luc Valere C. Brun², Marie-Claire Balle², Fatiou Alabi Bouraima1, \\ Tire Abdias Bossou' ${ }^{1}$, Nicolas H. Amegan ${ }^{3}$, Marius Claude Flatin', Marie-Therese Akélé-Akpo ${ }^{3}$ \\ ${ }^{1}$ Department of Surgery and Surgical Specialties, Faculty of Medicine, University of Parakou, Parakou, Benin \\ ${ }^{2}$ Department of Basic Sciences, Faculty of Medicine, University of Parakou, Parakou, Benin \\ ${ }^{3}$ Department of Basic Sciences, Faculty of Sciences and Health, University of Abomey-Calavi, Cotonou, Benin \\ Email: *speraoul@yahoo.fr
}

How to cite this paper: Hounkpatin, S.H.R., Brun, L.V.C., Balle, M.-C., Bouraima, F.A., Bossou, T.A., Amegan, N.H., Flatin, M.C. and Akélé-Akpo, M.-T. (2020) Histo-Epidemiological Profile of Head and Neck Cancers in Benin. International Journal of Otolaryngology and Head \& Neck Surgery, 9, 19-29.

https://doi.org/10.4236/ijohns.2020.91004

Received: November 22, 2019

Accepted: December 30, 2019

Published: January 2, 2020

Copyright () 2020 by author(s) and Scientific Research Publishing Inc. This work is licensed under the Creative Commons Attribution International License (CC BY 4.0).

http://creativecommons.org/licenses/by/4.0/

\begin{abstract}
Background: The collection of data on cancers is essential to assess their importance in a population and plan control strategies. In Benin as in many sub-Saharan Africa countries, cancer data are often not well informed. Purpose: To study the epidemiological and anatomopathological profiles of head and neck cancers. Methods: This was a descriptive cross-sectional study of head and neck cancers in Benin from January 2009 to 31 December 2014. These tumours were collected in the registers of the 5 anatomy-pathological laboratories in Benin as well as in that of the only hospital in the country that sends its requests for histological examination abroad. Results: During the period, 611 cases of head and neck tumour were reported, including 298 malignant cases, or $48.8 \%$. The average age was $45.3 \pm 18.7$ years (extremes: 1 year and 91 years) with a maximum of cases between 50 and 60 years (19.1\%). The sex ratio was 1.2 . The cancers occurred mainly in the pharynx (27.9\%), the oral cavity $(19.8 \%)$, the nose, sinuses and jaws (18.1\%), the thyroid $(12.8 \%)$, the salivary glands $(8.7 \%)$ and the larynx $(8.4 \%)$. They were of epithelial origin in $79.5 \%$ of cases, mainly squamous cell carcinomas (50.3\%) and lymphomas in $12.8 \%$ of cases. Conclusion: Head and neck cancer is preventable. A special place should be given to the fight against cancer in Benin. Strategies to prevent and manage these cancers cannot be put in place without accurate data collection.
\end{abstract}

\section{Keywords}

Cancer of the Head and Neck, Squamous Cell Carcinoma of the Head and Neck, Cancer of the Mouth, Cancer of the Larynx 


\section{Introduction}

Cancer, once considered a public health problem only in high-income countries, is now on the rise in developing countries and is the second leading cause of death worldwide after cardiovascular disease [1] [2] [3]. In sub-Saharan Africa as in many developing countries, cancer data are often not well informed; perhaps because cancer is perceived as a secondary health problem in the face of the importance of infectious disease [2] [4] [5] [6] [7]. However, the collection of information on cancers is essential to assess their importance in a population and plan control strategies [1] [8] [9]. In Benin, like other African countries, there is currently no truly national database for cancer data collection [2]. To get an idea of the situation in Benin regarding head and neck cancers, this study was undertaken with the objective of studying the epidemiological and pathological profiles of head and neck malignancies in Benin from 2009 to 2014.

Head and neck cancers taken as a whole are among the most frequent cancers in the world. These are the most common cancers in developing countries, particularly those in the oral cavity in South and Southeast Asian countries [10]. The incidence of head and neck cancers, underestimated in Africa but nevertheless increasing, varies from one region to another depending on lifestyle and the prevalence of risk factors [1] [11] [12]. Alcoholism and smoking are known to be the main risk factors for head and neck cancers, which explains the high male prevalence of these cancers (women making less use of them although the number of female smokers is increasing) [13] [14] [15] [16]. Nevertheless, a significant proportion of head and neck cancers in women and young people ( $<45$ years of age) cannot be attributed to tobacco or alcohol consumption, but to other risk factors [13]. There is consistent evidence that human papillomavirus (HPV) is responsible for a high proportion of oropharyngeal cancers in non-smokers and non-drinkers [17] [18] [19] [20]. Epstein Barr virus has been recognized as an etiological agent of nasopharyngeal carcinoma [14] [21]. Other risk factors involved in the occurrence of head and neck cancers include chewing betel, arec, tobacco, especially in South and Southeast Asia, and low socio-economic living standards [22] [23] [24].

\section{Materials and Methods}

This was a descriptive cross-sectional study that examined histologically confirmed head and neck malignancies from January 1, 2009 to December 31, 2014.

These tumours were collected in the registers of the 5 public and private pathological cytology laboratories in Benin at the time of the study as well as in the register of pathological results of the only hospital in the country that sends its requests for histological examination abroad (in Italy for partnership reasons).

All reports of pathological examinations of head and neck tissue masses (ear, rhino-sinus cavities, maxilla, oral cavity, salivary glands, larynx, pharynx, 
thyroid) whose histological diagnosis was a malignant tumour were used for the study. Pseudotumours (cysts, inflammatory granulomas, colloid goiter due to excess colloid substance and not to cell proliferation) and all cases whose sampling did not define the nature of the tumour were not included.

The variables studied were the age and sex of the patient, the location of the tumour and its histological type.

The data were collected from the registers and archives of the 6 institutions included in this study.

Data entry was made in EPIDATA 3.1 French version. The data analysis was carried out using the EPIINFO 3.5.1 software.

\section{Results}

\subsection{Frequency}

During the period, 611 cases of head and neck tumours were reported, including 298 malignant tumours representing $48.8 \%$ of all histologically confirmed head and neck tumours and an annual incidence of 49.7 cases per year.

\subsection{Age and Sex}

The average age was $45.3 \pm 18.7$ years with extremes of 1 year and 91 years. The modal class was the age group of [50 - 60] years old with $19.1 \%$ of cases. One hundred and sixty-three patients (54.7\%) were between the ages of 40 and 70 . Figure 1 shows the distribution of patients by age.

Malignant head and neck tumours concerned male subjects in 55\% of cases and female subjects in $45 \%$ of cases, i.e. a sex ratio equal to 1.2 .

\subsection{Headquarters}

Cancers were found in the pharynx in $27.9 \%$ of cases, in the oral cavity in $19.8 \%$

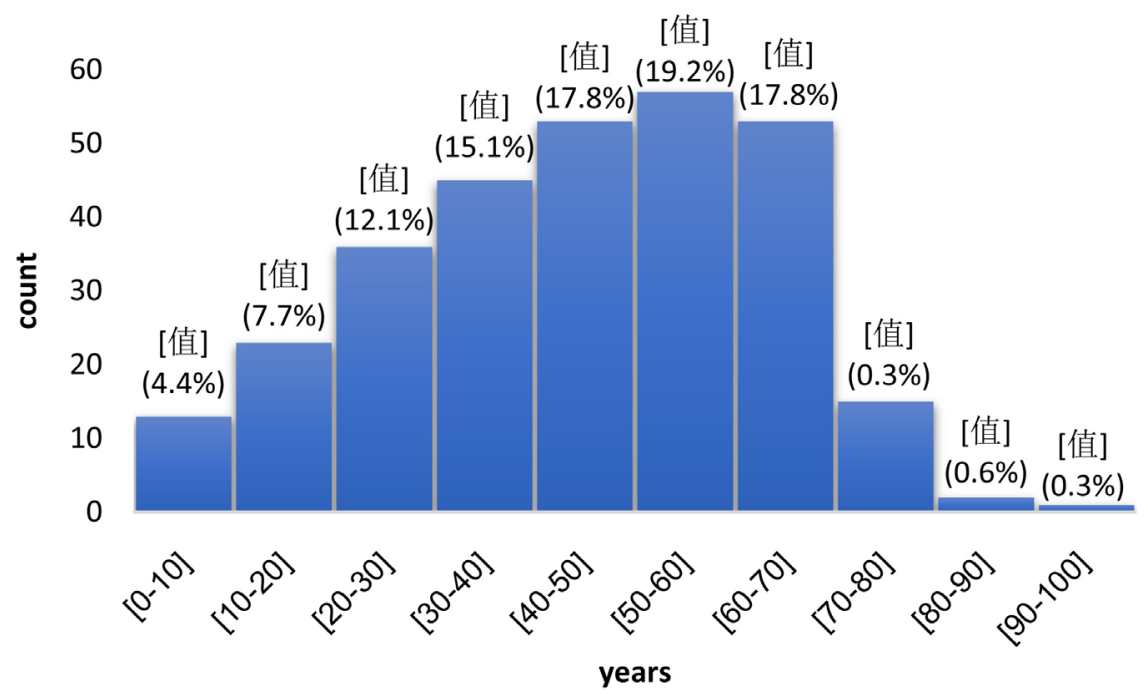

Figure 1. Distribution of patients by head and neck malignancies according to age of patients in Benin from 2009 to 2014. 
of cases, and in the nose, sinuses and jaws in $18.1 \%$ of cases. Table 1 shows the distribution of head and neck cancers by site.

\subsection{Histological Types}

Table 2 shows the distribution of head and neck cancers by histological type. Head and neck cancers were of epithelial origin in $79.5 \%$ of cases and lymphomas in $12.8 \%$ of cases.

Table 1. Distribution of patients by head and neck malignancies according to their location in Benin from 2009 to 2014.

\begin{tabular}{ccc}
\hline & Count & Percent \\
\hline Pharynx & 83 & 27.9 \\
Oral cavity & 59 & 19.8 \\
Nose, sinuses and jaws & 54 & 18.1 \\
Thyroid & 38 & 12.8 \\
Salivary glands & 26 & 8.7 \\
Larynx & 25 & 8.4 \\
Malignant cervical adenopathies & 10 & 3.3 \\
Ears & 3 & 1.0 \\
Total & $\mathbf{2 9 8}$ & $\mathbf{1 0 0 . 0}$
\end{tabular}

Table 2. Distribution of patients by head and neck malignancies according to their histological type in Benin from 2009 to 2014.

\begin{tabular}{|c|c|c|c|}
\hline & & Count & Percent \\
\hline \multirow{8}{*}{$\begin{array}{c}\text { Epithelial tumours } 237 \\
(79.5 \%)\end{array}$} & Squamous cell carcinoma & 150 & 50.3 \\
\hline & Papillary carcinoma & 26 & 8.7 \\
\hline & Adenocarcinoma & 16 & 5.4 \\
\hline & Cystic adenoid carcinoma & 12 & 4.0 \\
\hline & Follicular carcinoma & 8 & 2.7 \\
\hline & Muco-epidermal carcinoma & 4 & 1.3 \\
\hline & Undifferentiated carcinoma & 2 & 0.7 \\
\hline & Other carcinomas & 19 & 6.4 \\
\hline & Non-Hodgkin's lymphoma & 25 & 8.5 \\
\hline Lymphoma & Hodgkin's lymphoma & 8 & 2.7 \\
\hline \multirow[t]{4}{*}{$38(12.8 \%)$} & Burkitt's Lymphoma & 4 & 1.3 \\
\hline & Plasmocytoma & 1 & 0.3 \\
\hline & Malignant fibrous histiocytoma & 5 & 1.7 \\
\hline & Neuroblastoma & 3 & 1.0 \\
\hline \multirow[t]{3}{*}{ Soft tissue tumours $16(5.4 \%)$} & Angiosarcoma & 2 & 0.7 \\
\hline & Primary neuroectodermal tumor & 1 & 0.3 \\
\hline & Others & 5 & 1.7 \\
\hline Bone and cartilage tumours & Osteosarcome & 3 & 1.0 \\
\hline Melanocytic tumor & Melanoma & 4 & 1.3 \\
\hline Total & & 298 & 100.00 \\
\hline
\end{tabular}


Table 3 shows the most frequent histological type, the mean age of patients and the sex ratio by major sites of Head and neck cancers. Apart from the glands, the most frequent histological type of tumours was squamous cell carcinoma.

\section{Discussion}

In developed countries, the incidence of head and neck cancers is very high, well documented and has justified the implementation of control strategies that yield significant results [25] [26] [27] [28]. This is far from being the case in Africa where the reported incidences are generally hospital-based due to the absence of national case registration systems; however, various studies report remarkable incidences of head and neck cancers cases. In Burkina Faso, Sérémé et al. reported an annual incidence of 12.8 cases [29]; in Côte d'Ivoire, Kouassi-Ndjeundo et al. reported a hospital incidence of 13.6 cases per year [30]. Higher annual incidences were reported in Togo (41 cases) and Nigeria (47 cases), countries bordering Benin [31] [32]. In this study, the average number of annual cases in Benin as a whole was 49.7. These different numbers are far lower than those in developed countries but should not be considered reassuring because these cases do not really reflect reality because in our context, many patients do not reach the hospital due to financial, geographical or cultural accessibility problems. In addition, even if currently two thirds of head and neck cancers occur in developed countries, by 2030, the expected incidence of head and neck cancers is expected to exceed 1 million worldwide, most of which (73\%) will come from less developed countries due to population growth, lifestyle changes with inherent risk factors, improved registration systems [33] [34] [35] [36].

In Benin, the average age of patients with head and neck cancers was $45.3 \pm$ 18.7 years, however malignant tumours occurred in all age groups (1 to 91 years), and their incidence increased steadily over the years to reach a peak between 50 and 60 years. In several of the studies reported in Africa, the average age of patients was greater than 45 years with a maximum number of cases between the 6th and 7th decade [29] [30] [31] [37] [38]. A study in northwest Nigeria found a lower average age of patients (39.5 years) than that found in

Table 3. Most frequent histological type, mean age and sex-ratio by main Head and neck cancers sites in Benin from 2009 to 2014.

\begin{tabular}{cccc}
\hline & Most frequent histological type & Mean age & Sex-ratio \\
\hline Pharynx & Squamous cell carcinoma & $42.1 \pm 18.3$ & 2.0 \\
Oral cavity & Squamous cell carcinoma & $53.2 \pm 20.6$ & 1.1 \\
Nose, sinuses and jaws & Squamous cell carcinoma & $40.5 \pm 18.9$ & 0.9 \\
Thyroid & Papillary carcinoma & $43.4 \pm 16.9$ & 0.3 \\
Salivary glands & Cylindrome and adenocarcinoma & $37.6 \pm 16.4$ & 0.8 \\
Larynx & Squamous cell carcinoma & $57.4 \pm 12.5$ & 4.0 \\
\hline
\end{tabular}


general elsewhere in Africa and even in other parts of Nigeria with a sex ratio equal to 1.2 [32]. This led the authors to raise the possibility of the existence of risk factors other than tobacco and alcohol, including HPV infection. We are inclined to think the same thing in Benin in view of the great involvement of young patients on the one hand and female patients on the other. Indeed, in Benin 117 patients (39.3\%) were under 40 years of age with 72 of them (24.2\%) under 30 years of age and the sex ratio was 1.2. Considering other studies carried out in West Africa in neighbouring countries, except Côte d'Ivoire where the sex ratio was 4.3, the male predominance was not very high either, with a sex ratio of 1.45 in Ghana, and 1.55 in Togo and Burkina Faso [29] [30] [31] [39].

As well as the incidence, the frequency of malignancies by location varies from country to country and even from region to region within each country [26] [35] [40]. In developed countries where cancer data are well documented, an increasing trend is observed in locations where HPV infection plays a role in cancer occurrence (oral cavity, oropharynx) while in the larynx, for example, where cancer is mainly related to smoking, the trend is downward or stagnant [41] [42] [43] [44]. In West African countries neighbouring Benin, the most frequent sites for Burkina Faso were the larynx (28.12\%), thyroid (18.75\%), tonsil region (8.59\%); for Togo the oral cavity (36.2\%), the oropharynx (18.5\%) and the larynx (18.1\%); for Côte d'Ivoire the larynx (61.6\%), the oropharynx and the hypopharynx (20.7\%) and the naso-sinus cavities (7.3\%) [29] [30] [31]. In Benin, head and neck cancers were mainly located in the pharynx (27.9\%) and oral cavity (19.8\%), which are locations for which the role of oncogenic viruses (in addition to chronic smoking) is now well known. The sex ratios observed in these locations were 2 and 1.1 respectively. These sex ratios are well below the sex ratio of 4 observed in laryngeal cancers (classically recognized as induced mainly by chronic smoking) which came sixth position (8.4\%). In addition, the average age in laryngeal cancers was relatively higher compared to other main locations of head and neck cancers in Benin, suggesting risk factors other than tobacco that induce cancer, especially after prolonged use and therefore in relatively older subjects [45]. The other main locations were respectively the nose, sinus and jaw (18.1\%) in third position followed by the thyroid (12.8\%) and then the salivary glands (8.7\%). In these locations where tobacco is not traditionally incriminated, the predominance was female with sex ratios of 0.9 , 0.3 and 0.8 respectively.

Histologically, head and neck cancers in Benin were mainly epithelial tumours (79.5\%), particularly squamous cell carcinoma (50.3\%) located mainly in the upper aerodigestive tract (pharynx, oral cavity, nose, sine and jaw, larynx) while in the glands, it was papillary carcinoma $(8.7 \%$ in the thyroid gland with a large female predominance) and cystic adenoid carcinomas (4\% in the salivary glands). This predominance of squamous cell carcinoma has been widely reported in the literature [30] [32] [44] [46] [47] [48]. In second place far behind epithelial tumours came lymphomas (12.8\%) and these were mainly non-Hodgkin's malignant lymphomas. The same was true in Burkina Faso [29]. Lilly-Tariah 
reported in 2009 that in many centres in Nigeria the majority of head and neck cancers were of epithelial origin and mainly squamous cell carcinomas and lymphomas were the second most frequently observed cell type [49]. Sarcomas were rather rare as were other histological types of tumours, according to data in the literature [50] [51].

\section{Conclusion}

In developing countries where non-communicable diseases are on the rise, a special place should be given to the fight against cancer. The purpose of this study is to draw attention to the significant role played by head and neck malignant tumours, which are preventable cancers, in Benin and even in Africa. Strategies to prevent and manage these cancers cannot be put in place without accurate data collection, which is far from being the case at present. Close collaboration between ENT doctors, oncologists, histologists and health authorities is essential to find ways to set up truly national and accurate cancer data collection systems.

\section{Conflicts of Interest}

The authors declare no conflicts of interest regarding the publication of this paper.

\section{References}

[1] Fitzmaurice, C., Allen, C., Barber, R.M., Barregard, L., Bhutta, Z.A., Brenner, H., et al. (2017) Global, Regional, and National Cancer Incidence, Mortality, Years of Life Lost, Years Lived With Disability, and Disability-Adjusted Life-Years for 32 Cancer Groups, 1990 to 2015: A Systematic Analysis for the Global Burden of Disease Study. JAMA Oncology, 3, 524-548.

[2] Parkin, D.M., Ferlay, J., Jemal, A., Borok, M., Manraj, S.S., N’da, G.G., Ogunbiyi, J.O., Liu, B. and Bray, F. (2018) Cancer in Sub-Saharan. Africa. IARC Scientific Publications No. 167, International Agency for Research on Cancer, Lyon, France.

[3] Mishra, A. and Meherotra, R. (2014) Head and Neck Cancer: Global Burden and Regional Trends in India. Asian Pacific Journal of Cancer Prevention, 15, 537-550. https://doi.org/10.7314/APJCP.2014.15.2.537

[4] Ferlay, J., Soerjomataram, I., Ervik, M., Dikshit, R., Eser, S., Mathers, C., et al. (2013) GLOBOCAN 2012 Cancer Incidence and Mortality Worldwide: IARC Cancer Base No. 11. V.1.0. International Agency for Research on Cancer, Lyon, France.

[5] Somdyala, N.I.M., Parkin, D.M., Sithole, N. and Bradshaw, D. (2015) Trends in Cancer Incidence in Rural Eastern Cape Province; South Africa, 1998-2012. International Journal of Cancer, 136, 470-474. https://doi.org/10.1002/ijc.29224

[6] Leal, Y.A., Fernandez-Garrot, L.M., Mohar-Betancourt, A. and Meneses, A.-G. (2016) The Importance of Registries in Cancer Control. Salud Pública de México, 58, 309-316. https://doi.org/10.21149/spm.v58i2.7802

[7] Ly, M., Ly, A., Rodrigues, M., Loriot, Y., Deberne, M., Boudou-Rouquette, P., et al. (2010) Le cancer en Afrique, un nouveau défi sanitaire. Exemples du Mali et de l'association OncoMali. Bulletin du Cancer, 97, 965-968. 
https://doi.org/10.1684/bdc.2010.1134

[8] Malanda, J.N., Mbon, J.B.N., Bambara, A.T., Ibara, G., Minga, B., Epala, B.N., et al. (2013) Douze années de fonctionnement du registre des cancers de Brazzaville Twelve Years of Working of Brazzaville Cancer Registry. Bulletin du Cancer, 100, 135-139. https://doi.org/10.1684/bdc.2013.1701

[9] Parkin, D.M. (2008) The Role of Cancer Registries in Cancer Control. International Journal of Clinical Oncology, 13, 102-111. https://doi.org/10.1007/s10147-008-0762-6

[10] Joshi, P., Dutta, S., Chaturvedi, P. and Nair, S. (2014) Head and Neck Cancers in Developing Countries. Rambam Maimonides Medical Journal, 5, e0009. https://doi.org/10.5041/RMMJ.10143

[11] Adeola, H.A., Afrogheh, A.H. and Hille, J.J. (2018) The Burden of Head and Neck Cancer in Africa: The Status Quo and Research Prospects. South African Dental Journal, 73, 477-488. https://doi.org/10.17159/2519-0105/2018/v73no8a1

[12] Filleul, O., Preillon, J., Crompot, E., Lechien, J. and Saussez, S. (2011) Incidence of Head and Neck Cancers in Belgium: Comparison with World Wide and French Data. Bulletin du Cancer, 98, 1173-1183. https://doi.org/10.1684/bdc.2011.1456

[13] Hashibe, M., Brennan, P., Chuang, S.C., Boccia, S., Castellsague, X., Chen, C., et al. (2009) Interaction between Tobacco and Alcohol Use and the Risk of Head and Neck Cancer: Pooled Analysis in the International Head and Neck Cancer Epidemiology Consortium. Cancer Epidemiology, Biomarkers \& Prevention, 18, 541-550. https://doi.org/10.1158/1055-9965.EPI-08-0347

[14] Pezzuto, F., Buonaguro, L., Caponigro, F., Ionna, F., Starita, N., Annunziata, C., et al. (2015) Update on Head and Neck Cancer: Current Knowledge on Epidemiology, Risk Factors, Molecular Features and Novel Therapies. Oncology, 89, 125-136. https://doi.org/10.1159/000381717

[15] Kfouri, S.A., Neto, J.E., Koifman, S., Curado, M.P., Menezes, A., Daudt, A.W., et al. (2018) Fraction of Head and Neck Cancer Attributable to Tobacco and Alcohol in Cities of Three Brazilian Regions. Revista Brasileira de Epidemiologia, 21, e180005. https://doi.org/10.1590/1980-549720180005

[16] Wirth, N., Béguinot, E. and Martine, Y. (2019) Lutte contre le tabagisme en France: quoi de nouveau? La Revue du Praticien, 69, 653-657.

[17] Kim, L., King, T. and Agulnik, M. (2010) Head and Neck Cancer: Changing Epidemiology and Public Health Implications. Oncology, 24, 915-919.

[18] Marur, S. and Forastiere, A.A. (2016) Head and Neck Squamous Cell Carcinoma: Update on Epidemiology, Diagnosis, and Treatment. Mayo Clinic Proceedings, 91, 386-396. https://doi.org/10.1016/j.mayocp.2015.12.017

[19] Kreimer, A.R., Clifford, G.M., Boyle, P. and Franceschi, S. (2005) Cancer Human Papillomavirus Types in Head and Neck Squamous Cell Carcinomas Worldwide: A Systematic Review. Cancer Epidemiology, Biomarkers \& Prevention, 14, 467-475. https://doi.org/10.1158/1055-9965.EPI-04-0551

[20] Barrya, B. and Ortholanb, C. (2014) Papillomavirus Humain et Cancer ORL Human Papilloma Virus in Head and Neck Cancer. Cancer/ Radiothérapie, 18, 430-433. https://doi.org/10.1016/j.canrad.2014.06.003

[21] Fernandes, Q., Merhi, M., Raza, A., Inchakalody, V.P., Abdelouahab, N., Zar Gul, A.R., et al. (2018) Role of Epstein-Barr Virus in the Pathogenesis of Head and Neck Cancers and Its Potential as an Immunotherapeutic Target. Frontiers in Oncology, 8, 257. https://doi.org/10.3389/fonc.2018.00257

[22] Khawaja, M.R., Mazahir, S., Majeed, A., Malik, F., Merchant, K.A., Maqsood, M., et 
al. (2006) Chewing of Betel, Areca and Tobacco: Perceptions and Knowledge Regarding Their Role in Head and Neck Cancers in an Urban Squatter Settlement in Pakistan. Asian Pacific Journal of Cancer Prevention, 7, 95-100.

[23] Grandazzi, G., Babin, E. and van der Schueren, M. (2017) Cancer des VADS et comportements à risque. Psycho-Oncologie, 11, 233-237.

[24] Conway, D.I., Petticrew, M., Marlborough, H., Berthiller, J., Hashibe, M. and Macpherson, L.M. (2008) Socioeconomic Inequalities and Oral Cancer Risk: A Systematic Review and Meta-Analysis of Case-Control Studies. International Journal of Cancer, 122, 2811-2819. https://doi.org/10.1002/ijc.23430

[25] Siegel, R.L., Miller, K.D. and Jemal, A. (2019) Cancer Statistics, 2019. CA: A Cancer Journal for Clinicians, 69, 7-34. https://doi.org/10.3322/caac.21551

[26] Mourad, M., Jetmore, T., Jategaonkar, A.A., Moubayed, S., Moshier, E. and Urken, M.L. (2017) Epidemiological Trends of Head and Neck Cancer in the United States: A SEER Population Study. Journal of Oral and Maxillofacial Surgery, 75, 2562-2572. https://doi.org/10.1016/j.joms.2017.05.008

[27] Doobaree, I.U., Landis, S.H., Linklater, K.M., El-Hariry, I., Moller, H. and Tyczynski, J. (2009) Head and Neck Cancer in South East England between 1995-1999 and 2000-2004: An Estimation of Incidence and Distribution by Site, Stage and Histological Type. Oral Oncology, 45, 809-814.

https://doi.org/10.1016/j.oraloncology.2008.12.009

[28] Gawełko, J., Cierpiał-Wolan, M., Kawecki, A., Wilk, K., Pięciak-Kotlarz, D.B. and Sikorski, D. (2017) Comparative Analysis of the Incidence of Head and Neck Cancer in South-Eastern Poland and in Poland in the Years 1990-2012. Contemporary Oncology/ Współczesna Onkologia, 21, 77-82. https://doi.org/10.5114/wo.2017.66497

[29] Sérémé, M., Ouoba, W.J., Meda, C.H., Koueta, A., Noa, E.E.M., Bambara, C., et al. (2016) Les cancers ORL et cervico-faciaux au Burkina-Faso. La Revue Africaine dORL et de Chirurgie Cervico-Faciale, 16, 21-27.

[30] Kouassi-Ndjeundo, J., N’Gattia, K.V., Vroh, B.T.S., Badou-N’Guessan, K.E., Kouassi Dumas, P. and Yavo-Dosso, N. (2015) Epidémiologie et histopathologie des cancers des voies aérodigestives supérieures à Abidjan. La Revue Africaine dORL et de Chirurgie Cervico-Faciale, 15, 41-46.

[31] Darré, T., Bissa, H., Akloa, K.E., Pegbessou, E., Amana, B., N'guessan, A.A., et al. (2015) Epidemiological and Pathological Aspects of Head and Neck Cancers in Togo. Journal of Analytical Oncology, 4, 30-34. https://doi.org/10.6000/1927-7229.2015.04.01.5

[32] Akinshipo, A.W.O., Taiwo, A.O., Abdullahi, K., Fatimah. A.Y., Sahabi, S.M. and Ahmed, M.A. (2017) Head and Neck Cancers: An Histopathologic Review of Cases Seen in Three Tertiary Hospitals in Northwestern Nigeria. Clinical Science, 14, 113-118. https://doi.org/10.4103/jcls.jcls_18_17

[33] Vohra, P., Strobbia, P., Ngo, H.T., Lee, W.T. and Vo-Dinh, T. (2018) Rapid Nanophotonics Assay for Head and Neck Cancer Diagnosis. Scientific Reports, 8, Article No. 11410. https://www.nature.com/articles/s41598-018-29428-0 https://doi.org/10.1038/s41598-018-29428-0

[34] Byakodi, R., Byakodi, S., Hiremath, S., Byakodi, J., Adaki, S., Marathe, K., et al. (2012) Oral Cancer in India: An Epidemiologic and Clinical Review. Journal of Community Health, 37, 316-319. https://doi.org/10.1007/s10900-011-9447-6

[35] Gupta, B., Johnson, N.W. and Kumar, N. (2016) Global Epidemiology of Head and Neck Cancers: A Continuing Challenge. Oncology, 91, 13-23. 
https://doi.org/10.1159/000446117

[36] Mishra, A.1. and Meherotra, R. (2014) Head and Neck Cancer: Global Burden and Regional Trends in India. Asian Pacific Journal of Cancer Prevention, 15, 537-550. https://doi.org/10.7314/APJCP.2014.15.2.537

[37] Adoga, A.A., Kokong, D.D., Ma'an, N.D., Silas, O.A., Dauda, A.M., Yaro, J.P., et al. (2018) The Epidemiology, Treatment, and Determinants of Outcome of Primary Head and Neck Cancers at the Jos University Teaching Hospital. South Asian Journal of Cancer, 7, 183-187. https://doi.org/10.4103/sajc.sajc_15_18

[38] Onyango, J.F., Awange, D.O., Njiru, A. and Macharia, I.M. (2006) Pattern of Occurrence of Head and Neck Cancer Presenting at Kenyatta National Hospital, Nairobi. East African Medical Journal, 83, 288-291. https://doi.org/10.4314/eamj.v83i5.9435

[39] Larsen-Reindorf, R., Owusu-Afriyie, O., Acheampong, A., Boakye, I. and Awuah, B. (2014) A Six-Year Review of Head and Neck Cancers at the Komfo Anokye Teaching Hospital, Kumasi, Ghana. International Journal of Otolaryngology and Head \& Neck Surgery, 3, 271-278. https://doi.org/10.4236/ijohns.2014.35050

[40] Simard, E.P., Torre, L.A. and Jemal, A. (2014) International Trends in Head and Neck Cancer Incidence Rates: Differences by Country, Sex and Anatomic Site. Oral Oncology, 50, 387-403. https://doi.org/10.1016/j.oraloncology.2014.01.016

[41] Louie, K.S., Mehenna, H. and Sasieni, P. (2015) Trends in Head and Neck Cancers in England from 1995 to 2011 and Projected up to 2025. Oral Oncology, 51, 341-348. https://doi.org/10.1016/j.oraloncology.2015.01.002

[42] Braakhuis, B.J., Leeman, C.R. and Viisser, O. (2014) Incidence and Survival Trends of Head and Neck Squamous Cell Carcinoma in the Netherlands between 1989 and 2011. Oral Oncology, 50, 670-675. https://doi.org/10.1016/j.oraloncology.2014.03.008

[43] Conway, D.I., Purkayastha, M. and Chestnutt, I.G. (2018) The Changing Epidemiology of Oral Cancer: Definitions, Trends, and Risk Factors. British Dental Journal, 225, 867-873. https://doi.org/10.1038/sj.bdj.2018.922

[44] Boscolo-Rizzo, P., Zorzi, M., Del Mistro, A., Da Mosto, M.C., Tirelli, G., Buzzoni, C., et al. (2018) The Evolution of the Epidemiological Landscape of Head and Neck Cancer in Italy: Is There Evidence for an Increase in the Incidence of Potentially HPV-Related Carcinomas? PLoS ONE, 13, e0192621. https://www.ncbi.nlm.nih.gov/pmc/articles/PMC5802923/pdf/pone.0192621.pdf https://doi.org/10.1371/journal.pone.0192621

[45] Pelucchi, C., Gallus, S., Garavello, W., Bosetti, C. and Vecchia, C. (2006) Cancer Risk Associated with Alcohol and Tobacco Use: Focus on Upper Aero-Digestive Tract and Liver. Alcohol Research \& Health, 29, 193-198.

[46] Rousseau, A. and Badoual, C. (2012) Head and Neck: Squamous Cell Carcinoma: An Overview. Atlas of Genetics and Cytogenetics in Oncology and Haematology, 16, 145-155. https://doi.org/10.4267/2042/46948

[47] Siddiqui, M.S., Chandra, R., Aziz, A. and Suma, S. (2012) Epidemiology and Histopathological Spectrum of Head and Neck Cancers in Bihar, a State of Eastern India. Asian Pacific Journal of Cancer Prevention, 13, 3949-3953. https://doi.org/10.7314/APJCP.2012.13.8.3949

[48] Gilyoma, J.M., Rambau, P.F., Masalu, N., Kayange, N.M. and Chalya, P.L. (2015) Head and Neck Cancers: A Clinico-Pathological Profile and Management Challenges in a Resource-Limited Setting. BMC Research Notes, 8, Article No. 772. https://bmcresnotes.biomedcentral.com/articles/10.1186/s13104-015-1773-9 
https://doi.org/10.1186/s13104-015-1773-9

[49] Da Lilly-Tariah, O.B., Somefun, A.O. and Adeyemo, W.L. (2009) Current Evidence on the Burden of Head and Neck Cancers in Nigeria. Head \& Neck Oncology, 1, Article No.14. https://www.ncbi.nlm.nih.gov/pmc/articles/PMC2694192/ https://doi.org/10.1186/1758-3284-1-14

[50] Colreavy, M., Lacy, P., Hughes, J., Bouchier-Hayes, D., Brennan, P., O’Dwyer, A., et al. (2000) Head and Neck Schwannomas-A 10 Year Review. The Journal of Laryngology \& Otology, 114, 119-124. https://doi.org/10.1258/0022215001905058

[51] Sturgis, E.M. and Potter, B.O. (2003) Sarcomas of the Head and Neck Region. Current Opinion in Oncology, 15, 239-252.

https://doi.org/10.1097/00001622-200305000-00011 